\title{
Penyuluhan Peningkatan Kesadaran Hukum Masyarakat Terhadap Pengelolaan Sampah di Kota Pekanbaru Menurut Peraturan Daerah Kota Pekanbaru Nomor 4 Tahun 2000 Tentang Retribusi dan Kebersihan
}

\author{
Olivia Anggie Johar*1, Tri Novita Sari Manihuruk ${ }^{2}$ \\ 1,2 Fakultas Hukum Universitas Lancnag Kuning \\ *e-mail: oliviaanggiejohar@unilak.ac.id ${ }^{1}$ trinovitasari@yahoo.com²
}

\begin{abstract}
The waste problem in Pekanbaru City is not only the responsibility of the government but also the community. Pekanbaru City has a regulation that regulates waste management, namely PERDA Number 4 of 2000 concerning Cleanliness Retribution. The community must understand how the regulations related to waste management are to create a clean and sustainable environment. Therefore, Community Service activities by conducting counseling to increase legal awareness of the community in Limbungan Village. At this time the legal awareness of the community regarding waste management is still low. After the service, it can be seen that there is an increase in public understanding regarding public legal awareness regarding waste management in accordance with applicable regulations which can be seen from the pre-test and posttest questionnaires given to the community.
\end{abstract}

Keywords: Management, Waste, Pekanbaru City Regional Regulation Number 4 Year 2000

\begin{abstract}
Abstrak
Permasalahan sampah yang ada di Kota Pekanbaru tidak hanya menjadi tanggubjawab pemerintah tetapi juga masyarakat. Kota pekanbaru memiliki regulasi yang mengatur tentang pengelolaan sampah yaitu PERDA Nomor 4 Tahun 2000 tentang Retribusi Kebersihan. Masyarakat harus paham bagaimana pengaturan terkait pengelolaan sampah sehingga terciptanya lingkungan yang bersih dan lestari. Maka dari itu kegiatan Pengabdian Kepada Masyarakat dengan melakukan penyuluhan peningkatan kesadaran hukum terhadap masyarakat di Kelurahan Limbungan. Pada saat ini keasadaran hukum masyarakat terkait pengelolaan sampah masih rendah. Setelah dilakukan pengabdian terlihat bahwa terjadi peningkatan pemahaman masyarakat terkait kesadaran hukum masyarakat terkait pengelolaan sampah sesuai dengan peraturan yang berlaku yang dapat dilihat dari kuisioner pre test dan post test yang diberikan kepada masyarakat.
\end{abstract}

Kata kunci: Pengelolaan, Sampah, PERDA kota Pekanbaru Nomor 4 Tahun 2000

\section{PENDAHULUAN}

Permasalahan sampah merupakan permasalah yang genting dihadapi oleh masyarakat Indonesia. Peningkatan jumlah sampah yang ada dikarenakan oleh perilaku masyarakat itu sendiri yang membuang sampah secara sembarangan sehingga terjadi penumpukan sampah. Permasalahan sampah menjadi berita yang besar dimana penyelesaian permasalahannya masih menyisakan persoalan yang baru.

Sampah merupakan sisa dari bahan yang sudah tidak diperlukan yang belum memiliki nilai yang bernilai, berasal dari aktifitas manusia maupun alam. Sampah antara lain bersumber dari rumah tangga, perindustrian, rumah sakit, pasar dan lain-lain.

Sampah diartikan sebagai segala sesuatu yang padat yang tidak diinginkan lagi oleh pemiliknya. Sedangkan menurut Rancangan Undang-Undang tentang Sampah, sampah didefinisikan sebagai sisa suatu usaha atau kegiatan berupa zat organik atau anorganik padat atau setengah padat yang dapat terurai atau tidak dapat terurai yang tidak lagi berguna dan dibuang ke lingkungan, 
Pekanbaru merupakan kota yang sedang berkembang. Perkembangan suatu kota akan sejalan dengan meningkatnya permasalahan-permasalahan lingkungan hidup. Permasalahan lingkungan hidup yang salah satunya di hadapi oleh masyarakat adalah masalah sampah.

Sesuai dengan tujuan yang digariskan dalam Rencana Detil Tata Ruang, tujuannya adalah untuk menciptakan kota yang terencana dengan baik dalam segala aspek dengan tetap menjaga dan meningkatkan kualitas lingkungan saat ini. Dengan perencanaan dan aturan tersebut, diyakini pola pengelolaan sampah akan semakin baik dan tertata lebih baik, sehingga menghasilkan kota yang bersih dan ekosistem yang sehat.

Kesulitan ini juga muncul dalam peradaban kita yang belum mengembangkan kebiasaan hidup dan tidak menyadari masalah pengelolaan sampah seperti di mana membuang sampah, bagaimana menanganinya, dan sebagainya. Hal-hal inilah yang melatarbelakangi munculnya permasalahan sampah di Pekanbaru.

"Selain itu, pembuangan sampah oleh masyarakat (perilaku) ke dalam saluran atau sungai, serta pembuangan sampah yang dilakukan di sembarang tempat atau di tempat-tempat yang semestinya tidak boleh di pakai untuk membuang sampah-sampah tersebut. Padahal, di dalam peraturan daerah kota Pekanbaru yang tertuang dalam Perda Nomor 4 tahun 2000 tentang retribusi kebersihan, telah di cantumkan bahwa:"

"setiap orang atau badan yang memiliki atau menguasai bangunan dan/atau tanah/ lapangan terbuka, yang diduga akan menjadi tempat/ sumber sampah diwajibkan melengkapi/ menyediakan tempat sampah dengan ukuran yang mampu untuk menampung sampah dari sumber sampah serta bentuknya yang patut dan ditempatkan pada tempat yang mudah terjangkau dan atau diangkat"

Menurut Perda diatas, yang ditingkatkan adalah ketersediaan fasilitas pembuangan sampah untuk semua orang dan pembuangan sampah yang benar. Namun kenyataan di lapangan sangat berbeda. "Kondisi yang ada menunjukkan bahwa beberapa tempat tidak menyediakan tempat sampah, atau menyediakan tempat sampah yang tidak memenuhi kriteria. Atau mungkin, tempat sampahnya tersedia, tetapi menyisakan masyarakat dengan perilakunya yang sembarangan membuang sampah-sampah tersebut."

Dengan permasalahan-permasalahan tersebut maka perlu diadakan penyuluhan peningkatan kesadaran hukum masyarakat Kelurahan Limbungan Kecamatan Rumbai Timur Kota Pekanbaru terhadap pengelolaan sampah menurut Peraturan Daerah Kota Pekanbaru Nomor 4 Tahun 2000 Tentang Retribusi Dan Kebersihan agar masyarakat yang menjadi mitra dapat hidup di lingkungan dan ekosistem yang baik.

\section{METODE}

Prosedur kerja akan dibagi menjadi beberapa bagian, yang pertama adalah tahap persiapan. Dalam tahap ini yang dilakukan adalah menyediakan semua peralatan yang diperlukan untuk kegiatan, melakukan penelitian literatur, dan berkoordinasi dengan organisasi lain untuk melakukan kegiatan. dilakukan.

Kedua, kunjungan lapangan untuk memutuskan di mana kegiatan penyuluhan akan

Ketiga, menyiapkan sumber daya yang akan dipamerkan dalam kegiatan tersebut dengan merancang slide nasihat hukum. Memperbanyak jumlah bahan penyuluhan yang akan disesuaikan dengan jumlah peserta kegiatan.

Keempat, melaksanakan kegiatan penyuluhan mengenai "Peraturan Daerah Kota Pekanbaru Nomor 4 Tahun 2000 tentang Retribusi dan Kebersihan" yang dilakukan oleh tim pelaksana dari dosen-dosen Fakultas Hukum Universitas Lancang Kuning dengan memberikan materi pemahaman. 
Teknik penilaian dilakukan dengan cara menghitung jumlah peserta dan memberikan kuesioner terkait materi kepada mereka baik sebelum dan sesudah kegiatan. Keberhasilan kegiatan ini diukur dari 1) terjalinnya hubungan yang baik dan kerjasama antara pelaksana kegiatan dengan pihak Kelurahan, 2) tingkat kehadiran peserta minimal 50\% dari jumlah undangan, 3) interaksi dua arah antara pembicara dan peserta dalam kegiatan, 4) peningkatan pemahaman peserta kegiatan terkait materi yang disampaikan, dan 5) peningkatan pemahaman peserta kegiatan diukur dengan membagikan angket yang dilakukan sebelum dan sesudah penyuluhan dilakukakan.

\section{HASIL DAN PEMBAHASAN}

A. Hasil Kegiatan Pengabdian Kepada Masyarakat di Kelurahan Limbungan Kecamatan Rumbai Timur Kota Pekanbaru terhadap pengelolaan sampah menurut Peraturan Daerah Kota Pekanbaru Nomor 4 Tahun 2000 Tentang Retribusi Dan Kebersihan

Hasil kegiatan pengabdian berupa evaluasi peningkatan pemahaman Masyarakat di Kelurahan Limbungan Kecamatan Rumbai Timur Kota Pekanbaru terhadap pengelolaan sampah menurut "Peraturan Daerah Kota Pekanbaru Nomor 4 Tahun 2000 Tentang Retribusi Dan Kebersihan". Hasil evaluasi kegiatan menunjukkan bahwa peserta kegiatan pengabdian kepada masyarakat dapat memahami materi yang disampaikan oleh tim pengabdian masyarakat yang berasal dari Fakultas Hukum Universitas Lancang Kuning.

Indikator pemahaman tercantum dalam hasil kuisioner yang diberikan pada saat kegiatan. Masyarakat memilih jawaban pada kuisoner terdiri atas pilihan jawaban yang benar dan jawaban yang salah. Jawaban pada kuisioner terdapat dalam materi yang dibagikan dan materi yang disampaikan oleh tim pengabdian.

Luaran dari kegiatan ini adalah peningkatan kesadaran masyarakat terhadap pengelolaan sampah di Desa Limbungan Kecamatan Rumbai Timur Kota Pekanbaru sebagaimana ditetapkan dalam "Peraturan Daerah Kota Pekanbaru Nomor 4 Tahun 2000 tentang Retribusi dan Kebersihan". Evaluasi tersebut mengungkapkan bahwa peserta pengabdian masyarakat memahami materi yang disampaikan oleh tim pengabdian masyarakat dari dosen Fakultas Hukum Universitas Lancang Kuning.

Temuan kuesioner yang dibagikan sepanjang sesi mencakup indikator pemahaman masyarakat. Masyarat memilih jawaban yang benar dari daftar jawaban YA dan TIDAK pada angket. Jawaban dari anket yang dibagikan kepada peserta, terdapat dalam materi yang disampaikan dan dibagikan oleh tim pengabdian.

\section{B. Pembahasan}

\section{Pelaksanaan Kegiatan}

Pelaksanaan penyuluhan dilakukan dengan metode ceramah dan dialog. Metode ceramah digunakan pada sesi pertama. Pemateri memberikan pemaparan tentang pengelolaan sampah di Desa Limbungan Kecamatan Rumbai Timur Kota Pekanbaru sesuai "Peraturan Daerah Kota Pekanbaru Nomor 4 Tahun 2000 tentang Retribusi dan Kebersihan".

Peserta penyuluhan yaitu masyarakat Kelurahan Limbungan Kecamatan Rumbai Kota Pekanbaru mendengarkan serta memperhatikan materi yang disampaikan pemateri. Sebelum kegiatan penyuluhan, terlebih dahulu peserta penyuluhan diberikan kuisioner dengan beberapa pertanyaan mengenai materi tentang pemahaman Masyarakat di Kelurahan Limbungan Kecamatan Rumbai Timur Kota Pekanbaru terhadap pengelolaan sampah menurut "Peraturan Daerah Kota Pekanbaru Nomor 4 Tahun 2000 Tentang Retribusi Dan Kebersihan". Tujuan diberikannya kuisioner kepada peserta diawal penyampaian materi adalah untuk mengukur tingkat pemahaman dan pengetahuan peserta terkait materi yang akan disampaikan. 
Setelah dilaksanakannya kegiatan penyuluhan oleh tim pengabdian masyarakat dengan cara menyampaikan materi serta diskusi dengan peserta, peseta penyuluhan diberikan kembali kuisioner yang sama dengan kuisioner sebelumnya untuk mengetahui ada atau tidak nya peningkatan pemahaman peserta penyuluhan setelah mendapatkan materi yang telah diberilan oleh tim pengabdian kepada masyarakat. Hasilnya adalah adanya meningkatanya pemahaman masyarakat terhadap materi yang telah disampaikan. Indikasi lainnya yang dapat dilihat atas keberhasilan kegiatan ini adalah tingginya tingkat antusiasme masyarakat dalam mengajukan pertanyaan-pertanyaan yang sesuai dengan keadaan yang masyarakat alami di lapangannya.

Kegiiatan penyuluhan hukum ini dilaksanakan di Musholla Alhidayah yang terletak di kelurahan Limbungan Kecamatan Rumbai Timur Pekanbaru, pada Hari Minggu, 30 Mei 2021. Tingkat keberhasilan Kegiatan ini dapat dinilai dengan tolak ukur sebagaiberikut:

a. Jumlah peserta yang hadir sesuai dengan jumlah undangan yang disebarkan yaitu sebanyak15 orang.

b. Terjalinnya Kerjasama yang sangat baik antara peserta dan Tim Pelaksana Kegiatan sehingga kegiatan berjalan lancer.

c. Peserta penyuluhan hukum sangat bersemangat dan antusias mengikuti semua rangkaian kegiatan yang dimulai dari pemaparan materi hingga sesi tanya jawab.

Pada pelaksanaan kegiatan terjadi interaksi berupa tanya jawab antara tim pengabdian masyarakat dengan peserta. Pertanyaan diantaranya diajukan oleh Pak Nasri (masyarakat) yaitu apakah ada aturan yang mewajibkan menyediakan tempat sampah? Tim menjawab berdasarkan pada aturan hukum "Peraturan Daerah Kota Pekanbaru Nomor 4 Tahun 2000 Tentang Retribusi Dan Kebersihan Pasal 2 ayat (1)" :

"Setiap orang atau badan yang memiliki atau menguasai bangunan dan/ atau tanah/ lapangan terbuka, yang diduga akan menjadi tempat/ sumber sampah diwajibkan melengkapi/ menyediakan tempat sampah dengan ukuran yang mampu untuk menampung sampah dari sumber sampah serta bentuknya yang patut dan ditempatkan pada tempat yang mudah terjangkau dan atau diangkat."

Dalam Pasal 2 ayat (1) sudah sangat jelas dikatakan bahwasannya masyarakat diwajibkan memiliki tempat sampah yang menyesuaikan dengan sampah yang dihasilkan setiap rumahnya. Masyarakat juga diberi pemahaman agar sebelum mebuang sampah ketempat sampah, terlebih dahulu sampah tersebut harus dipisahkan antara sampah kering dan sampah yang basah serta dimasukan kedalam kantong, agar memudahkan petugas untuk mengangkutnya. Hal tersebut sesuai dengan ketentuan Pasal 5 yang berbunyi:

"Sampah yang berkumpul didalam tempat sampah sebagai mana yang dimaksud dalam ayat (1) Pasal 4 Peraturan Daerah ini, harus dikemas kedalam kantong atau sejenisnya dan terlebih dahulu dipisahkan antara sampah kering dan sampah basah selanjutnya kemasan dimaksud diangkut dibuang dan diletakkan ke/di TPS dengan rapi antara pukul 19.00 WIB sampai denganpukul 05.00 WIB."

Selanjutnya pertanyaan dari Ibu Nurhayati. Apakah sampah boleh dibakar? Tim menjawab: sasmpah-sampah yang dihasilkan apabila sepanjang diperkirakan mudah terbakar dan dirasaa tidak mengganggu tetangga atau lingkungan sekitarnya serta tidak menimbulkan dampak lingkungan, maka sampah-sampah tersebut dapat dibakar pada waktu atau jam 14.0018.00. Hal ini sesuai dengan Pasal 4 Ayat (3):

"Sampah-sampah yang terkumpul didalam tempat sampah atau lobang (tanah yang digali) sebagaimana dimaksud dalam ayat (2) pasal 2 Peraturan Daerah ini, sepanjang diduga mudah terbakar dan tidak menganggu tetangga sekitarnya tidak menimbulkan dampak lingkungan maka sampah tersebut dapat dibakar ditempat ituantara pukul 14.00 WIB sampai dengan pukul 18.00 WIB atau dapat pula ditanam/ ditimbun sebagaimana mestinya." 
Pertanyaan selanjutnya oleh bapak Amurnis. Apakah hukumanya apabila kita tidak taat pada Peraturan tentang sampah ini? Tim menjawab: apabila kita atau subjek hukum tidak menaati atau melanggar aturan yang sudah dikeluarkan oleh pemerintah daerah Kota Pekanbaru yang dalam hal ini adalah "Peraturan Daerah Kota Pekanbaru Nomor 4 Tahun 2000 Tentang Retribusi Dan Kebersihan maka akan dikenakan pidana berupa kurungan atau denda paling banyak sebesar Rp 5.000.000., hal ini sesuai dengan Pasal 14 Ayat (1)" :

"Pelanggaran terhadap ketentuan-ketentuan dalam Peraturan Daerah ini dapat diancamdengan pidana kurungan paling lambat 6 (enam bulan) atau denda sebanyakbanyaknya Rp. 5.000.000,- (lima juta rupiah)."

\section{Evaluasi Kegiatan}

Saat kegiatan penyuluhan hukum, tim memberikan kuesioner pretest dan post test yang bersifat tertutup (objektif):

Pre Test:

\begin{tabular}{|c|c|c|c|}
\hline \multirow{2}{*}{ No } & \multirow{2}{*}{ Pertanyaan } & \multicolumn{2}{|c|}{ Pilihan } \\
\hline & & YA & TIDAK \\
\hline 1 & $\begin{array}{l}\text { Apakah masyarakat sudah mengetahui } \\
\text { Regulasi terkait pengelolaan sampah di Kota } \\
\text { Pekanbaru? }\end{array}$ & $40 \%$ & $60 \%$ \\
\hline 2 & $\begin{array}{l}\text { Apakah warga mengetahui yang menjadi } \\
\text { larangan dalam perda pengelolaan samapah } \\
\text { di Kota Pekanbaru? }\end{array}$ & $\begin{array}{c}46,67 \\
\%\end{array}$ & $53,33 \%$ \\
\hline 3 & $\begin{array}{l}\text { Apakah warga mengetahui bagaimana } \\
\text { proses pengelolaan sampah sesuai perda } \\
\text { pengelolaan samapah di Kota Pekanbaru? }\end{array}$ & $\begin{array}{c}33,34 \\
\%\end{array}$ & $66,66 \%$ \\
\hline 4 & $\begin{array}{l}\text { Apakah warga mengetahui terkait } \\
\text { retribusi dan tata cara pembayaran } \\
\text { pengelolaan sampah dalam perda pengelolaan } \\
\text { samapah di Kota Pekanbaru? }\end{array}$ & $20 \%$ & $80 \%$ \\
\hline
\end{tabular}

Pos Test:

\begin{tabular}{clcc}
\hline No & \multicolumn{1}{c}{ Pertanyaan } & YA & TIDAK \\
\hline 1 & $\begin{array}{l}\text { Apakah masyarakat sudah mengetahui } \\
\text { Regulasi terkait pengelolaan sampah di Kota } \\
\text { Pekanbaru? }\end{array}$ & $100 \%$ & $0 \%$ \\
2 & $\begin{array}{l}\text { Apakah warga mengetahui yang menjadi } \\
\text { larangan dalam perda pengelolaan samapah } \\
\text { di Kota Pekanbaru? }\end{array}$ & $100 \%$ & $0 \%$ \\
3 & $\begin{array}{l}\text { Apakah warga mengetahui bagaimana } \\
\text { proses pengelolaan sampah sesuai perda } \\
\text { pengelolaan samapah di Kota Pekanbaru? } \\
\text { Apakah warga mengetahui terkait } \\
\text { retribusi dan tata cara pembayaran } \\
\text { pengelolaan sampah dalam perda pengelolaan } \\
\text { samapah di Kota Pekanbaru? }\end{array}$ & $0 \%$ \\
\end{tabular}

Sebanyak 15 angket/kuisioner diberikan tim pengabdian masyarakat kepada peserta penyuluhan untuk mengevaluasi kegiatan. Tim penyuluhan memberikan atau menyampaikan 
lima belas angket/kuisoner kepada peserta, dan peserta dapat melingkari jawaban yang benar untuk setiap item dalam kuesioner. Survei dipisahkan menjadi dua bagian, satu sebelum dan satu setelah bahan disampaiakn. Tujuannya adalah untuk melihat sejauh mana pemahaman peserta meningkat sebelum dan sesudah konten diberikan. Setiap pertanyaan pada kuesioner, serta tanggapan dari peserta, menunjukkan pemahaman mereka.

Evaluasi dilaksanakan untuk mengetahui sejauh mana pengetahuan peserta kegiatan yaitu masyarakat Kelurahan Limbungan mengenai pengelolaan sampah menurut "Peraturan Daerah Kota Pekanbaru Nomor 4 Tahun 2000 tentang Retribusi Kebersihan".

Hasil evaluasi peningkatan pemahaman pengetahuan masyarakat peserta penyuluhan adalah diawali dengan pertanyaan pertama pada kuisioner, yaitu apakah masyarakat sudah mengetahui Regulasi terkait pengelolaan sampah di Kota Pekanbaru? Pilihan jawaban atas pertanyaan tersebut adalah (A) YA (B) TIDAK. Peserta kegiatan yang menjawab jawaban YA adalah berjumlah 6 orang atau $40 \%$ dari jumlah peserta, sedangkan untuk jawaban TIDAK berjumlah 9 orang atau $60 \%$ dari jumlah peserta. Setelah mengikuti penyuluhan hukum PKM Hasil evaluasi pengetahuan peserta untuk pertanyaan pertama pada kuisioner, yaitu apakah masyarakat sudah mengetahui Regulasi terkait pengelolaan sampah di Kota Pekanbaru? Pilihan jawaban atas pertanyaan tersebut adalah (A) YA (B) TIDAK. Peserta kegiatan menjawab pertanyan dengan benar yaitu semuanya menjawab YA (100\%).

Hasil evaluasi peningkatan pemahaman pengetahuan masyarakat peserta penyuluhan melalui pertanyaan kedua pada kuisioner, yaitu apakah warga mengetahui yang menjadi larangan dalam perda pengelolaan samapah di Kota Pekanbaru? Pilihan jawaban atas pertanyaan tersebut adalah $(A)$ YA (B) TIDAK. Peserta kegiatan yang menjawab jawaban YA adalah berjumlah 7 orang atau $46,67 \%$ dari jumlah peserta, sedangkan untuk jawaban TIDAK berjumlah 8 orang atau 53,33 \% dari jumlah peserta. Setelah mengikuti penyuluhan hukum PKM Hasil evaluasi pengetahuan peserta untuk pertanyaan kedua pada kuisioner, yaitu apakah warga mengetahui yang menjadi larangan dalam perda pengelolaan samapah di Kota Pekanbaru? Pilihan jawaban atas pertanyaan tersebut adalah (A) YA (B) TIDAK. Peserta kegiatan menjawab pertanyan dengan benar yaitu semuanya menjawab YA (100\%).

Hasil evaluasi peningkatan pemahaman pengetahuan masyarakat peserta penyuluhan adalah melaui pertanyaan ketiga pada kuisioner, apakah warga mengetahui bagaimana proses pengelolaan sampah sesuai perda pengelolaan samapah di Kota Pekanbaru? Pilihan jawaban atas pertanyaan tersebut adalah (A) YA (B) TIDAK. Peserta kegiatan yang menjawab jawaban YA adalah berjumlah 5 orang atau 33,34 \% dari jumlah peserta, sedangkan untuk jawaban TIDAK berjumlah 10 orang atau $66,67 \%$ dari jumlah peserta. Setelah mengikuti penyuluhan hukum PKM Hasil evaluasi pengetahuan peserta untuk pertanyaan ketiga pada kuisioner, yaitu Apakah warga mengetahui bagaimana proses pengelolaan sampah sesuai perda pengelolaan samapah di Kota Pekanbaru? Pilihan jawaban atas pertanyaan tersebut adalah (A) YA (B) TIDAK. Peserta kegiatan menjawab pertanyan dengan benar yaitu semuanya menjawab YA (100 \%).

Hasil evaluasi peningkatan pemahaman pengetahuan masyarakat peserta penyuluhan adalah melaui pertanyaan keempat pada kuisioner, apakah warga mengetahui terkait retribusi dan tata cara pembayaran pengelolaan sampah dalam perda pengelolaan samapah di Kota Pekanbaru? Pilihan jawaban atas pertanyaan tersebut adalah (A) YA (B) TIDAK. Peserta kegiatan yang menjawab jawaban YA adalah berjumlah 3 orang atau $20 \%$ dari jumlah peserta, sedangkan untuk jawaban TIDAK berjumlah 12 orang atau $80 \%$ dari jumlah peserta. Setelah mengikuti penyuluhan hukum PKM Hasil evaluasi pengetahuan peserta untuk pertanyaan ketiga pada kuisioner, yaitu Apakah warga mengetahui terkait retribusi dan tata cara pembayaran pengelolaan sampah dalam perda pengelolaan samapah di Kota Pekanbaru? Pilihan jawaban atas pertanyaan tersebut adalah (A) YA (B) TIDAK. Peserta kegiatan menjawab pertanyan dengan benar yaitu semuanya menjawab YA (100\%).

Para peserta penyuluhan sangat antusias mengikuti seluruh rangkaian penyuluhan, mulai dari penyampaian materi hingga sesi tanya jawab, dimana mereka tidak pernah 
mendapatkan informasi dan penjelasan dari narasumber dari perguruan tinggi maupun pemerintah, terbukti dengan banyaknya pertanyaan yang diajukan oleh para peserta.

\section{KESIMPULAN}

Masyarakat di Kelurahan Limbungan Kecamatan Pesisir Rumbai mampu memahami informasi yang diberikan oleh tim pengabdi. Temuan kuesioner yang disajikan selama kegiatan mencakup indikator pemahaman mereka. Masyarakat peserta penyuluhan memilih jawaban ya atau tidak untuk pertanyaan ya atau tidak dari kuesioner. Informasi yang disebarluaskan dan materi yang disampaikan oleh tim pengabdi, dapat dijadikan informasi dan pengetahuan dalam memberikan tanggapan terhadap kuisioner yang diberikan. Berbagai kekhawatiran dan keingintahuan peserta terkait materi pengelolaan sampah sesuai "Perda Kota Pekanbaru Nomor 4 Tahun 2000 tentang Retribusi dan Kebersihan" dapat terjawab dengan tepat ketika peyuluha hukum, tanya jawab dan diskusi dilakukan.

\section{DAFTAR PUSTAKA}

Arimbi dan Santosa, 1993. Peran serta Masyarakat Dalam Pengelolaan Lingkungan, WALHI dan YLBHI, Jakarta.

Fauzi A. 2006. Ekonomi Sumber Daya Alam dan Lingkungan, Gramedia Pustaka Utama, Jakarta.

Honneyta, P. 1993. Faktor-faktor yang mempengaruhi Partisipasi Masyarakat Terhadap Lingkungan Hidup, Univ.Syiah Kuala Banda Aceh Hasil Penelitian.

Hadiwiyoto, S, 2002 Penanganan dan Pemanfaatan Sampah, Yayasan Idayu, Jakarta.

Hartono, 2000. Perencanaan Sistem Pengelolaan Persampahan, Universitas Indonesia Press, Jakarta.

Indonesia, Peraturan Daerah Kota Pekanbaru No. 4 Tahun 2000 tentang Retribusi Kebersihan.

Ningsih, A. T. R., \& Siswati, L. (2021). Pengolahan Sampah Rumah Tangga Menjadi Kompos di Kelurahan. Labuh Baru Timur Pekanbaru. Dinamisia : Jurnal Pengabdian Kepada Masyarakat, 5(4).

Johar, Olivia Anggie. 2019, ."Pencemaran Sungai Siak Di Kota Pekanbaru Dan Penegakan Hukum Pidana Lingkungan" , JISPO: Jurnal Ilmu Sosial dan Ilmu Politik ,Vol 9 No 2, 2019, Bandung: Fakultas Ilmu Sosial dan Ilmu Politik UIN Sunan Gunung Djati Bandung

Johar, Olivia Anggie. 2021, Peningkatan Pemahaman Masyarakat Terhadap Penegakan Hukum Lingkungan Di Kelurahan Lembah Sari Kecamatan Rumbai Pesisir Kota Pekanbaru, Vol. 1 No. 1 (2021): Consen: Indonesian Journal of Community Services and Engagement

Johar, Olivia Anggie. 2021, Realitas Permasalahan Penegakan Hukum Lingkungan Di Indonesia, Vol 15, No 1 (2021): Jurnal Ilmu Lingkungan

Noer.H, 1999, Tingkat Partisipasi Masyarakat Dalam Pelaksanaan Pengelolaan Sampah Pemukiman.Bekasi, PSL Univ.45.

Simatupang, TB. 1970. Partispasi dalam Pembangunan Wilayah.

Soemarwoto, 0. 2001.Analisis Mengenai Dampak Lingkungan, Gadjah Mada University Press, Yogyakarta.

Undang-undang 32 Tahun 2009 tentang Perlindungan dan Pengelolaan Lingkungan Hidup 